\title{
A Study on Foreign Direct Investment Agriculture in China
}

\author{
Lixin Tang \\ School of Management, Yangtze University \\ Jingzhou 434023, China \\ E-mail: hbguosuzhen@163.com
}

\begin{abstract}
This paper describes the existing statement of foreign direct investment in agriculture in China firstly, and then analyzes some possible limiting factors about the shortage of FDI in agriculture in China. Finally, some measures and suggestions are presented.
\end{abstract}

Keywords: Agricultural, Foreign direct, Investment, Limiting factors

In recent years, foreign direct investment in the agricultural utilization of foreign capital has become the main channel. By the end of 2005, Chinese direct investment in the agricultural utilization of foreign capital amount has more than 32.9 billion U.S. dollars. China's agricultural use of foreign investment funds to make up for the domestic shortage of agricultural inputs, and the introduction of foreign advanced technology and equipment, and fine varieties and advanced management experience, which promoted the development of agricultural product processing industry, improved the level of industrialization of agriculture and promoted rural and agricultural reform. But at the same time, the objective situation such as the structure is not quite reasonable can not be ignored.

\section{China's foreign direct investment in the agricultural use of the status quo}

1) Foreign direct investment in the agricultural utilization of foreign capital has become the main channel. " $85 "$ In the past, China's agricultural use of foreign investment to indirect investments, Major international organizations are non-reimbursable assistance and a variety of financial loans, Funds are subject to provide the United Nations system, international organizations and international agencies, Foreign direct investment share of less than $20 \%$.Entered the last century 90's, the This situation changed dramatically. "Eighth Five-Year Plan" period, Foreign investment has gradually become the main peasant forms the use of foreign capital, Accounted for 62.8\%."Ninth Five-Year Plan" period, Increase foreign investment, In 1995 accounted for $95.6 \%$,In recent years, virtually $100 \%$ of all foreign direct investment in agriculture.

2) Agricultural use of foreign direct investment in small scale. With China's reform and opening-up continues to expand, Agricultural use of foreign capital has been relatively rapid growth, From 1999 to 2006 of 8 years, Agriculture 4130 projects utilizing foreign capital, Amount of contracted foreign investment 8.388 billion U.S. dollars. 5 years the number of projects were 456, 484, 536, 571, 674, 518, 433 and 458. Amount of contracted foreign investment of 761 million U.S. dollars, 692 million U.S. dollars, 962 million U.S. dollars, 794 million U.S. dollars, 1.389 billion U.S. dollars, 1.208 billion U.S. dollars, 1.147 billion U.S. dollars and 1.435 billion U.S. dollars. Over the same period, the country of foreign direct investment amounts to 40.319 billion U.S. dollars, respectively, 40.715 billion U.S. dollars, 46.878 billion U.S. dollars, 52.743 billion U.S. dollars, 53.505 billion U.S. dollars, 60.63 billion U.S. dollars, 72.406 billion U.S. dollars, 69.47 billion U.S. dollars. According to statistics, the agricultural use of foreign capital utilization of foreign capital in the country the proportion of the total amount of less than 4\%,As of April 2006, foreign direct investment in agriculture in the amount of foreign direct investment accounted for only $1.93 \%$ of total (Source: China Investment Guide website http://www.gov.cn). With China's foreign direct investment compared to the agricultural use of foreign direct investment scale is still a big gap.

3) Industry and regional distribution unbalanced. China's agricultural areas and the use of foreign capital continue to broaden the scope of the project cover all provinces, municipalities and autonomous regions, including the agriculture, forestry, water, livestock, fisheries in all aspects of the industry. But by 2005 the industrial structure of foreign direct investment in distribution as follows: the primary industry accounted for $1.96 \%$, secondary industry accounted for $68.69 \%$, the tertiary industry accounted for $29.36 \%$.As of 2005 , the eastern, central, western region for foreign direct investment: the eastern region accounted for 84.85 percent, the central region accounted for $8.87 \%, 4.37 \%$ accounted for the western region, the relevant departments accounted for 1.09\%.(Source: China Investment Guide website: http://www.gov.cn)Agricultural use of foreign direct investment and the geographical distribution of China's overall foreign direct investment is basically the same geographical distribution, with marked regional agglomeration effects 
4) Direct investment of transnational corporations begin production aspect of agriculture in China. Breaking the previous foreign investment concentrated in China's agricultural processing and marketing aspect of the program .The new trend that from "vendors" to "farmer" means it will have a strong impact on the traditional Chinese agricultural plant model, organizations and so on.

Japan's top brewers, "Asahi" beer company with the "Itochu" and "Sumitomo" chemical industry ', Ltd. "together at Shandong Laiyang rented 1300 acres of land plan to adopt organic farming methods to engage greenhouse and dairy farming. China gave 500 acres dairy farm which the rent is to be free for three years and set up electricity and built a road leading to the field.The Japanese side to pay the other land lease fees, the first five years of 800 yuan per mu each year, and thereafter every five years an increase of 200 million, the contract period of 20 years. Asahi Breweries PRESIDENT Yuzo Seto repeatedly said after the success of the "model" in China, they will clone twenty or thirty of the same items.

Macao henghe fruit industry in the Mainland, mainly engaged in fruit, after March 2003 it began to change the "sell" to "species", engaged in Chongqing Jiangjin 10 million mu of citrus production base, the use of "company to provide seeds, technical services + peasant farmers association management + plant + company unified acquisition" mode of operation.

French prestige Universal are one of the global top 500 enterprises, it's Tropicana orange juice industry in the world's leading. Zhong County, Chongqing is the world's citrus production on the most suitable one of the three lots in 1997, beginning at the prestigious Universal Zhongxian and farmers partnership to build a base of citrus orchards, a few short years, the project investment of 6 billion yuan (With China's investment and Farmer investment and labor investment), including 150,000 Al-acre orchards, world-class technology center.

5) Growing form of investment diversification. General there is a joint venture, cooperation and sole proprietorship in three forms, one of Hong Kong businessmen largest selection of joint ventures, followed by Chinese and foreign cooperation, sole proprietorship at least. Because Hong Kong businessmen can invest in the use of forms of cooperation on behalf of Mainland enterprises to obtain loans, tax also have concessions. Hong Kong businessmen operating in agriculture are generally integrated operation, such a comprehensive construction industry as far as possible, operators are related, such as species' dependent binding, feed, processing and marketing of connected vertical and horizontal contact-related, this is an industry-oriented business policy.

\section{China's agricultural sector use of foreign direct investment constraints}

1) China's current agricultural production to home-based small-scale farmers decentralized mode of production also accounted for a large proportion. Farmers do not have a strong concept of market-oriented agricultural production specialization, scale and operation of the low level of organization, together with many people will be less, backward agricultural plant production technology, coupled with large-scale agricultural investment, and long cycle by natural conditions and many Variable factors affecting large, capital-output scale effects, etc., it is difficult to effectively attract foreign investment in the modernization of large-scale.

2) Although agriculture has been included in the country to encourage foreign investment in industry, but in the policy has not been effective on the embodiment. Such as foreign investment in comprehensive agricultural development and eco-tourism on agriculture in the use of rural collective land on the long duration of the examination and approval procedures cumbersome and not reflect the corresponding incentive measures; We encourage foreign investment to improve the barren hills, flood, etc., to encourage foreign investment in comprehensive agricultural development in central and western regions, but did not introduce differentiated preferential treatment; In addition, foreign investment in agriculture and investment in the general processing and manufacturing in the examination and approval management, tax breaks and financing conditions, there is no difference between an objective impact on the enthusiasm of foreign capital to enter.

3) Our country is lagging behind the legislative work. Agricultural areas, especially agricultural use of foreign capital flow of the service sector the lack of corresponding laws and regulations guide. In accordance with China's accession to the WTO commitments, China's accession to the WTO will be at 2-4 years after the permit foreign enterprises established in China engaged in agriculture, forestry, animal husbandry, fisheries-related services, joint ventures;. Permit the establishment of a joint venture warehousing services; Permiti foreign service enterprises engaged in chemical fertilizer, agriculture, plastic sheeting and other agricultural means of production, wholesale and retail business. However, the current relevant laws and regulations have not yet introduced, foreign investment in the above-mentioned areas of agricultural services are still no laws.

4) China's agricultural management system in agricultural products between the production and marketing, between domestic and foreign trade, production, between production and investment management exist mutual disjiont. Regional blockade, industry segmentation and monopoly as well as the Department irregular trading practices, agricultural products, storage, transport, domestic sales, exports and so there is a foreign trade monopoly franchise and export licensing and quota requirements, not only on a much greater extent, bound by our country agricultural production, circulation and import and export, while foreign investment in China's agriculture and agricultural products to enter the field of operation also constitutes a major obstacle. 


\section{China's agricultural sector to expand the use of foreign direct investment measures and recommendations}

1) Continue to intensify our country in the agricultural infrastructure and scientific research on the input. Strengthen national agricultural industrialization and modernization of the guide, and strive to enhance the capacity of agricultural scientific and technological innovation, vigorously develop industrial management of agriculture, increase agricultural enterprises of various ownership, including the processing, circulation, import and export support for enterprises, the establishment of an international agricultural information release mechanism, actively promote international agricultural cooperation, vigorously develop the characteristics of agriculture, ecological agriculture, precision agriculture and water-saving energy-saving high-efficiency agriculture, improve agricultural productivity and the quality of agricultural producers, and enhance cooperation with foreign competition in the capacity for attracting foreign investment to create a good the basic conditions and external environment.

2) Speed up the legislative work in the field of agriculture, the agricultural sector for foreign investment to be effective guidance and supervision. After China's accession to the WTO for agriculture and especially the commitment of opening up service sectors in agriculture. We must actively organize relevant experts and scholars in related fields to speed up research on the job, fully draw on foreign experience in the agricultural utilization of foreign capital and combined with the current world trend of agricultural development and national conditions of China's agricultural development characteristics, speed up the introduction is in line with the WTO rules can effectively protect and promote our country's agricultural development-related laws and regulations, foreign investment in agriculture on the Service to be effective guidance and management.

3) The agricultural sector to attract foreign investment to do indirect investment and direct investment in both. Agricultural production affected by natural conditions, relatively large, many uncertainties, and the scale of agricultural production and high investment, long-term, objective constraints on the private sector and corporate investment enthusiasm and the World Bank and other international financial organizations to provide agricultural loans, has been the financing of agriculture in developing countries are the main channel. This requires that government agencies must be in the agricultural finance to play an active role. Relevant government agencies, therefore our country should continue to intensify our work, active use of foreign non-interest bearing and low-interest agricultural loans, increase our country agro-ecological environment and agricultural infrastructure inputs. At the same time, combined with our country's current economic development characteristics and trends of international capital flows, speed up the implementation of the existing well on the foreign direct investment in the field of China's agricultural policies, an appropriate adjustment of agricultural production, processing, circulation, marketing and foreign trade related taxes and fees, especially in agricultural products to further enhance the export tax rebate rate, increase the foreign tax, land use, financing and other aspects related to the encouragement and incentives, and further expand the scale and scope of agriculture and opening to the outside world, continue to devolve authority for approval, to simplify procedures reflect the country really effective to encourage foreign direct investment policies favoring agriculture.

4) Deepening of China's agricultural management and agricultural products circulation system. Agricultural products in the region to break up the blockade and trade restrictions, as soon as possible open, unified, competitive and orderly market system, and accelerate the establishment of more liberal, in favor of expanding exports of foreign trade system. On agricultural production, processing and circulation of the industry's domestic enterprises and foreign-invested enterprises equal treatment given to foreign-invested enterprises in agricultural production and operation and at the right to operate import and export and quota management on the basis of equal treatment, and further relaxed restrictions on foreign investment in the processing of agricultural products export enterprises, foreign trade rights for foreign investment in agriculture to create a more convenient and efficient market environment and the flow of supporting service system.

5) Combination of different countries and regions, foreign investment in agriculture and the characteristics of our country to strengthen and guide the direction of foreign investment. For instance: For Japan and Korea, because of the domestic market is highly developed, the cost of production higher, while our country is relatively far from its domestic market with a near, low labor cost advantages, and actively guide the two countries to invest in our country agricultural product processing industry, such as production and processing of vegetables and fruit juice processing projects, will be our country as part of its agricultural products processing base. For Europe and the United States and other developed countries, in view of their investment in Chinese agriculture are optimistic about China's huge potential consumer market characteristics, and actively guide the investors in Britain and the United States and other developed countries to invest in our country's advanced technology-based agricultural projects, to give impetus to our country related to agricultural production and agricultural products processing technologies improve the level of.

\section{References}

Feng, Xuguang. (2003). The impact and the status quo of China's agriculture in attracting foreign direct investment. The world economy, 10:25-29.

Huang, Zhuhui, \& Lv, Lica. (2005). China's agricultural use of foreign direct investment (FDI) Research. Journal of China Agricultural University, (Social Sciences), 2:12-16.

Lv, Licai, Gao, Yurong, \& Huang, Zhuhui. (2007). China's agricultural direct utilization of foreign direct investment in the status quo, Problems and Solutions. Economic issues, 1:76-78. 